\title{
Acute coinfection with hepatitis B and hepatitis $C$ viruses
}

\author{
Brian M Yan MD FRCPC, Samuel S Lee MD FRCPC
}

BM Yan, SS Lee. Acute coinfection with hepatitis B and hepatitis C viruses. Can J Gastroenterol 2005;19(12):729-730.

Acute coinfection of hepatitis B virus (HBV) and hepatitis C virus (HCV) is rare. The few previously reported cases all describe acute HBV followed by acute HCV, leading to HBV clearance but chronic $\mathrm{HCV}$. This is the first reported case of acute concurrent infection and spontaneous clearance of both HBV and HCV.

Key Words: Acute hepatitis B; Acute hepatitis C; Clearance; Coinfection

cute coinfection of hepatitis B virus (HBV) and hepatitis $C$ Avirus (HCV) is rare but more prevalent in intravenous drug abusers (1). The few previous cases all describe acute HBV followed by acute HCV, leading to HBV clearance but chronic HCV (1-4). We present a patient with acute coinfection of HBV and HCV, and subsequent spontaneous clearance of both viruses.

\section{CASE PRESENTATION}

A 54-year-old Caucasian man presented with a transient flulike illness in September 2003. After apparent recovery, a recurrence of symptoms occurred in October 2003, with extreme fatigue, lethargy, right upper quadrant pain and jaundice. He admitted to one episode of shared injection drug use in late June 2003. Other habits included intranasal cocaine and marijuana smoking sporadically over the previous 15 to 20 years, and unprotected and condom-protected sex with prostitutes. Alcohol intake was approximately two to three drinks daily. Past medical history included mild asthma controlled with salbutamol, salmeterol and fluticasone, and possible Reiter's syndrome.

The only abnormality on the physical examination was jaundice. Encephalopathy, ascites, hepatosplenomegaly and stigmata of chronic liver disease were absent.

Viral serology and liver chemistry confirmed acute coinfection with HBV and HCV (Figure 1 and Table 1). A complete blood count, electrolyte levels and tests of renal and liver synthetic function were normal. Screening tests for hemochromatosis, Wilson's disease, alpha-1-antitrypsin deficiency and autoimmune disease were negative. An abdominal ultrasound was normal.

By December 2003, he was completely asymptomatic, without any treatment, and all liver chemistry had returned to normal. Repeat testing in February and September 2004 confirmed clearance of both HBV and HCV.

\section{Une co-infection aiguë aux virus de l'hépatite B et de l'hépatite $\mathrm{C}$}

La co-infection aiguë au virus de l'hépatite B (VHB) et au virus de l'hépatite $\mathrm{C}(\mathrm{VHC})$ n'est pas monnaie courante. Les quelques cas déjà déclarés font tous état d'un VHB aigu suivi d'un VHC aigu, entraînant une clairance du VHB mais un VHC chronique. Le présent patient est le premier cas déclaré d'infection aiguë concomitante et de clairance spontanée tant du VHB que du VHC.

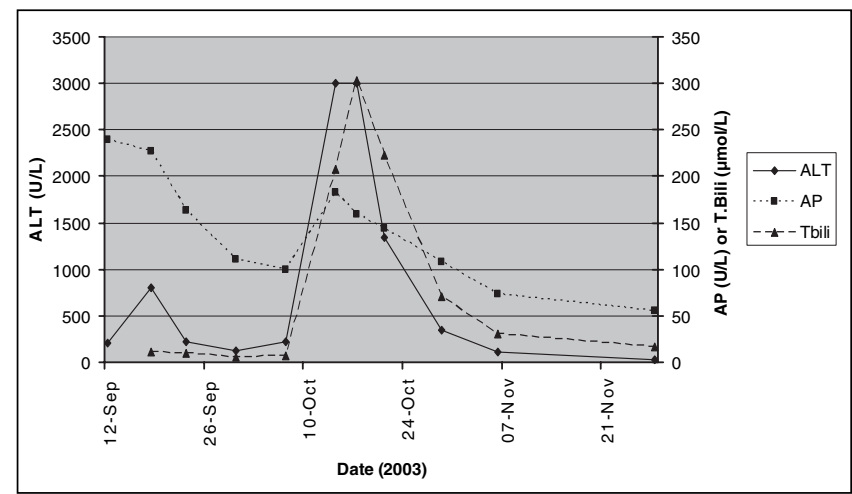

Figure 1) Time course of patient's liver chemistry and serology. ALT Alanine aminotransferase; AP Alkaline phosphatase; Tbili Total bilirubin

TABLE 1

Time course of patient's liver chemistry and serology

\begin{tabular}{|c|c|c|c|c|c|c|}
\hline & $\begin{array}{l}\text { Sept 12, } \\
2003\end{array}$ & $\begin{array}{l}\text { Sept 18, } \\
2003\end{array}$ & $\begin{array}{l}\text { Sept 30, } \\
2003\end{array}$ & $\begin{array}{c}\text { October 17, } \\
2003\end{array}$ & $\begin{array}{l}\text { February } \\
2004\end{array}$ & $\begin{array}{l}\text { Sept } \\
2004\end{array}$ \\
\hline $\mathrm{HBsAg}$ & + & & & & - & - \\
\hline Anti-HBs & - & & & & + & + \\
\hline Anti-HBc* & - & - & & & & + \\
\hline $\mathrm{HBeAg}$ & & & & & - & - \\
\hline Anti-HBe & & & & & + & + \\
\hline $\mathrm{HBV} \mathrm{DNA}^{\dagger}$ & & & & 8,400 copies $/ \mathrm{mL}$ & - & - \\
\hline Anti-HCV & - & IND & + & & & \\
\hline HCV RNA & & & & + & - & - \\
\hline
\end{tabular}

*Total in September (Sept) 2003, and total and immunoglobulin M in Sept 2004; 'Hepatitis B virus (HBV) DNA (Cobas Amplicor, Roche Diagnostics, USA) (Abbott 3rd-generation enzyme immunoassay). Anti-HBc Hepatitis $B$ core antibody; Anti-HBe Hepatitis B e antibody; Anti-HBs Hepatitis B surface antibody, Anti-HCV Hepatitis $C$ virus antibody; $H B e A g$ Hepatitis $B$ e antigen; HBsAg Hepatitis B surface antigen; IND Indeterminate; ULN Upper limit normal; - Negative; + Positive

Liver Unit, University of Calgary, Calgary, Alberta

Correspondence: Dr SS Lee, 3330 Hospital Drive Northwest, Calgary, Alberta T2N 4N1. Telephone 403-220-8457, fax 403-270-0995, e-mailsamlee@ucalgary.ca

Received for publication June 8, 2005. Accepted June 14, 2005 


\section{DISCUSSION}

Chronic coinfection of HBV and HCV is well known and relatively common. Coinfection seems to be associated with reciprocal inhibition of each virus and low levels of viremia. In chronic HBV carriers, acute HCV infection tends to suppress HBV replication (5). Acute coinfection has led to chronic $\mathrm{HCV}$ infection in all previous cases. This is the first reported patient with acute, concurrent infection and spontaneous clearance of both viruses.

The alternative possibility that our patient had acute HCV in the setting of chronic HBV cannot be completely ruled out. Indeed, risk factors for HBV infection were present dating back 20 years. However, at the initial presentation in September 2003, hepatitis B surface antigen ( $\mathrm{HBs} A g$ ) was detected but hepatitis B core antibody (anti-HBc) (total and immunoglobulin $\mathrm{M}$ ) was undetectable. Both total and immunoglobulin $\mathrm{M}$ anti-HBc were detected later. Because HBsAg is the first serological marker of an acute HBV infection, detected even before anti-HBc, this argues strongly for an acute HBV infection. In addition, the biphasic pattern of alanine aminotransferase elevation suggests consecutive acute infections (2-4).

Previous patients have shown acute HBV followed by HCV infection $(3,4)$. The patients reported by Coppola et al $(4)$ did not show HCV RNA until 30 days after illness and anti-HCV seroconversion at 45 days. They postulated that the acute HBV infection delayed expression of the HCV genome.

In our patient, we cannot determine which virus induced hepatitis first. The 10-week incubation period between the injection episode and the first onset of symptoms is compatible with either virus. We believe that HCV appeared first, based on the initial moderate alanine aminotransferase elevation and the timing of the anti-HCV seroconversion. The month delay between detection of $\mathrm{HBs} \mathrm{Ag}$ and the onset of the second hepatitis episode is certainly compatible with an acute HBV infection.

It is well known that the probability of clearance of HCV is significantly improved with an acute presentation with inflammation and jaundice. Acute HBV infection in immunocompetent adults almost always leads to clearance rather than chronic viral carriage. Our patient demonstrates these principles. In summary, our case represents acute coinfection and spontaneous clearance of both HBV and HCV.

\section{REFERENCES}

1. Rodriguez M, Navascues CA, Marinez A, et al. Hepatitis C infection in patients with acute hepatitis B. Infection 1992;20:316-9.

2. Mimms LT, Mosley JW, Hollinger FB, et al. Effect of concurrent acute infection with hepatitis $\mathrm{C}$ virus on acute hepatitis $\mathrm{B}$ virus infection. BMJ 1993;307:1095-7.

3. Chu CM, Liaw YF. Simultaneous acute hepatitis B virus and hepatitis $C$ virus infection leading to fulminant hepatitis and subsequent chronic hepatitis C. Clin Infect Dis 1995;20:703-5.

4. Coppola N, Marrocco C, Di Caprio D, et al. Acute hepatitis B and C virus coinfection: A virological and clinical study of 3 cases. Clin Infect Dis 2003;36:528-32.

5. Chu CM, Yeh CT, Liaw YT. Viral superinfection in previously unrecognized chronic carriers of hepatitis B virus with superimposed acute fulminant versus nonfulminant hepatitis. J Clin Microbiol 1999;37:235-7. 


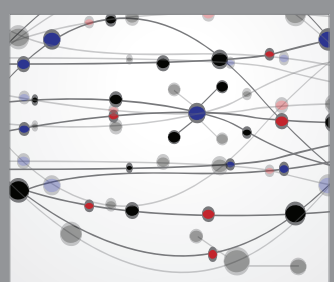

The Scientific World Journal
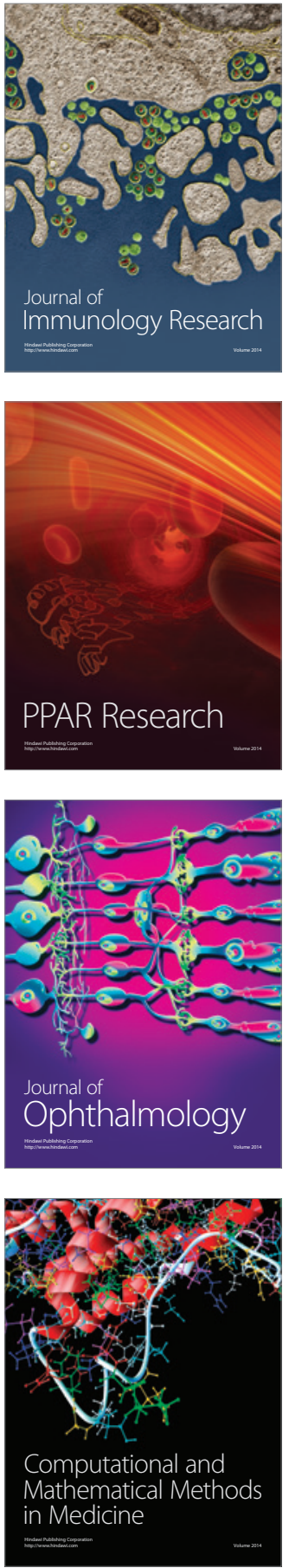

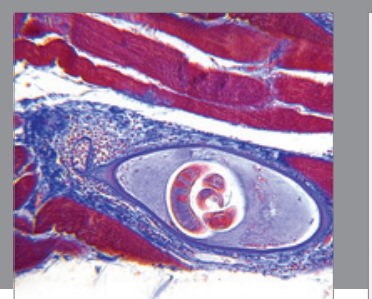

Gastroenterology Research and Practice

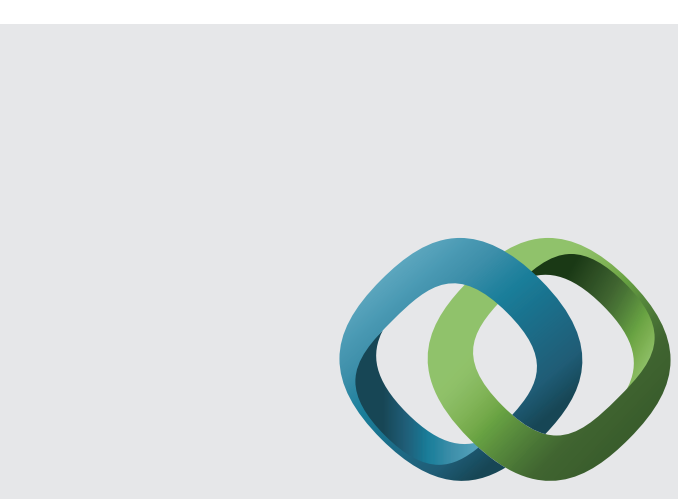

\section{Hindawi}

Submit your manuscripts at

http://www.hindawi.com
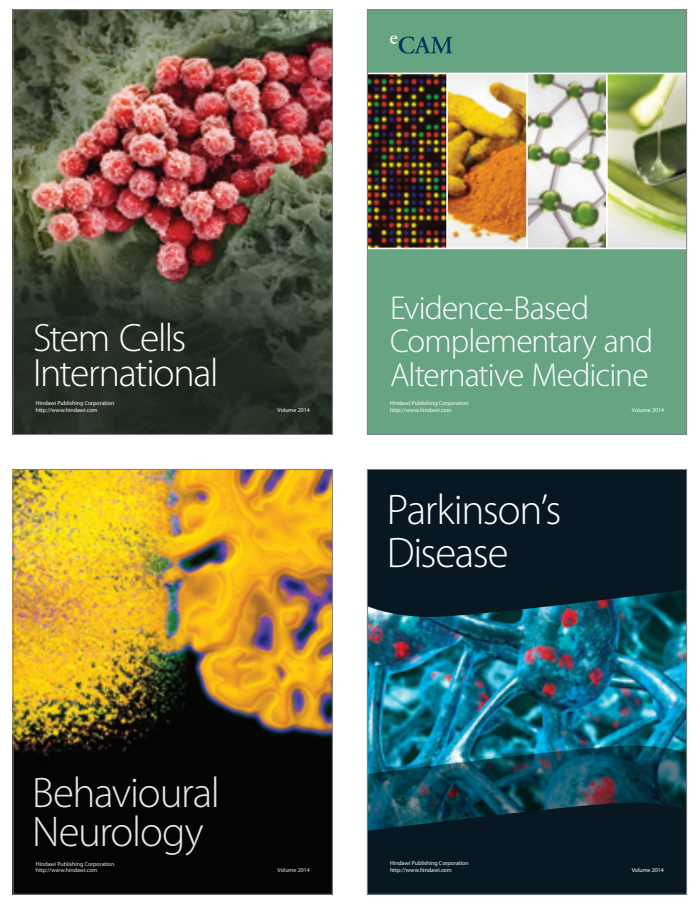
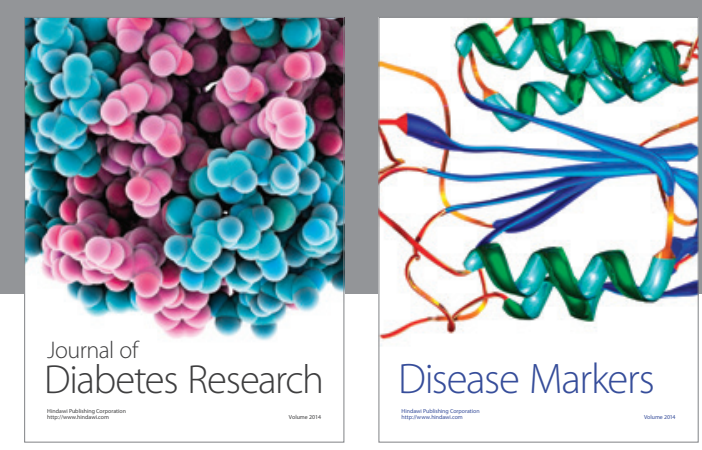

Disease Markers
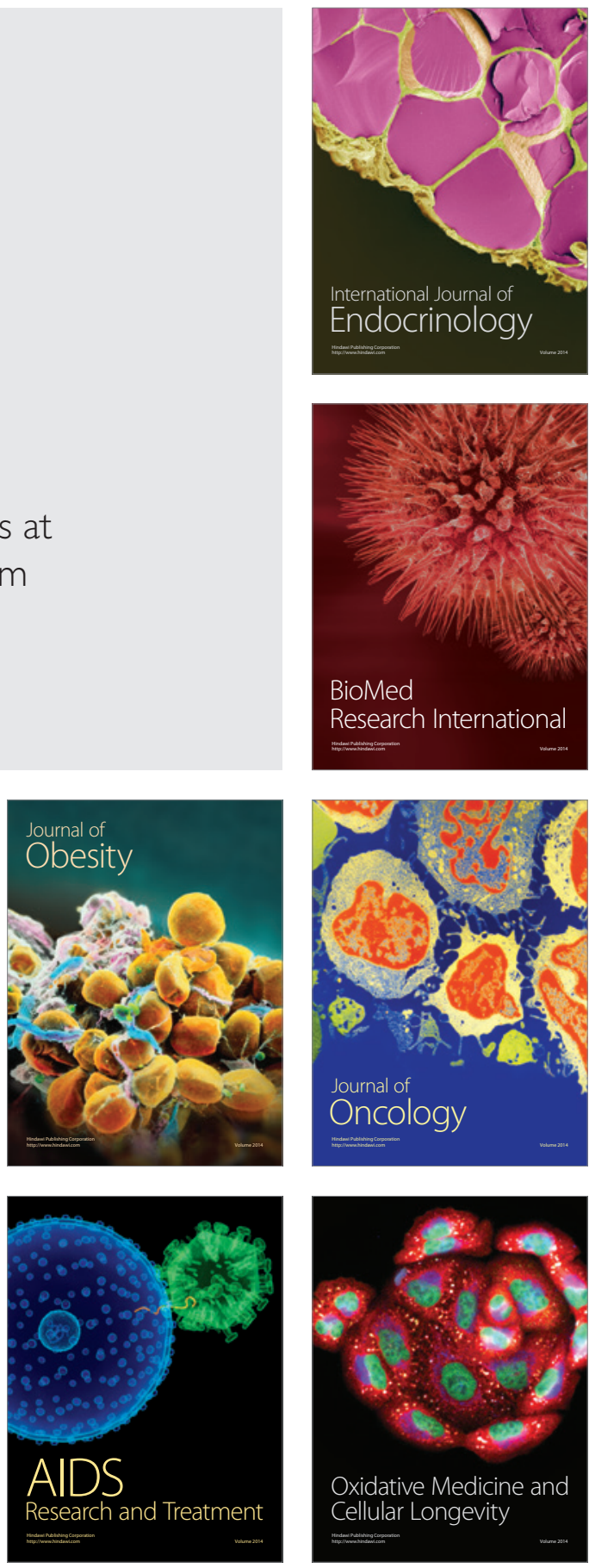